\title{
Salicylic Acid Accumulation in Barley Is Pathogen Specific but Not Required for Defense-Gene Activation
}

\author{
Laurence Vallélian-Bindschedler, Jean-Pierre Métraux, and Patrick Schweizer \\ Institut de Biologie Végétale, 3 rte Albert-Gockel, Université de Fribourg, $\mathrm{CH}-1700$ Fribourg, Switzerland \\ Accepted 8 March 1998.
}

\begin{abstract}
Barley (Hordeum vulgare) seedlings were inoculated with the biotrophic pathogen Erysiphe graminis f. sp. hordei, the biotrophic nonhost pathogen $E$. graminis f. sp. tritici, and the necrotrophic nonhost pathogen Pseudomonas syringae pv. syringae. The levels of free salicylic acid and of salicylic-acid conjugates remained low after infection with E. graminis f. sp. hordei or E. graminis f. sp. tritici while they increased after inoculation with $P$. syringae pv. syringae. Pathogenesis-related proteins PR1, PR3 (chitinase), PR5 (thaumatin-like), and PR9 (peroxidase) accumulated after inoculation with all three pathogens.
\end{abstract}

Additional keywords: powdery mildew, PR proteins.

Many plants, including barley, mount a multifaceted defense response when they are attacked by plant pathogens. In barley, the defense responses induced by the powdery mildew fungus Erysiphe graminis f. sp. hordei (Egh) include cell-wall appositions (papillae), accumulation of pathogenesis-related (PR) proteins, enhanced production of $\mathrm{H}_{2} \mathrm{O}_{2}$, and hypersensitive cell death (reviewed by Collinge et al. 1993; ThordalChristensen et al. 1997). In tobacco, cucumber, and Arabidopsis thaliana, the dicotyledonous model plants for systemic acquired resistance (SAR), it was shown that, in addition to several of the above-mentioned defense responses, the infected leaves accumulate high amounts of salicylic acid (SA) (Malamy et al. 1990; Métraux et al. 1990; Uknes et al. 1993). There exist several models wherein SA plays a role in the accumulation of $\mathrm{H}_{2} \mathrm{O}_{2}$ and PR proteins and in the onset of hypersensitive cell death (reviewed by Ryals et al. 1996; Schneider et al. 1996; Shirasu et al. 1997). Moreover, SA was demonstrated to be an indispensable ingredient of SAR in tobacco and A. thaliana (Delaney et al. 1994; Gaffney et al. 1993; Vernooij et al. 1994). On the other hand, very little is known about the role of SA in pathogenesis and induced resistance in cereals (Silverman et al. 1995). Here, we report on SA levels and PR-protein accumulation in barley following inoculation with the biotrophic pathogen Egh, the biotrophic, nonhost pathogen Erysiphe graminis f. sp. tritici (Egt), and the ne-

Corresponding author: Patrick Schweizer; Telephone: +41-1-385 42 60; Fax: +41-1-385 42 04; E-mail: pschweiz@ botinst.unizh.ch

Present address of Patrick Schweizer: Institut für Pflanzenbiologie, Zollikerstrasse 107, Universität Zürich, CH-8008 Zürich, Switzerland. crotrophic, nonhost pathogen Pseudomonas syringae pv. syringae (Pss).

Six-day-old barley (Hordeum vulgare L.) seedlings, cv. Golden Promise, were heavily inoculated with Swiss field isolates of Egh or Egt, resulting in approximately 10 conidia $\mathrm{mm}^{-2}$, followed by extraction of SA or PR proteins. Pss, a wheat isolate, was grown overnight in Luria broth at $28^{\circ} \mathrm{C}$ (Smith and Métraux 1991; Smith et al. 1991). For inoculation, $1 \times 10^{9} \mathrm{CFU} \mathrm{ml} \mathrm{m}^{-1}$ in $\mathrm{H}_{2} \mathrm{O}$ were injected into primary leaves with a $1-\mathrm{ml}$ syringe without needle. By this method, approximately 50 to $66 \%$ of the leaf was infiltrated. Mock-inoculated leaves were injected with $\mathrm{H}_{2} \mathrm{O}$ alone. Inoculated plants were kept in the same greenhouse as control or E. graminis-infected plants. For extraction of SA and PR proteins from Pssinfiltrated leaves, entire leaves were used, including the necrotic, central part as well as the apparently healthy, noninfiltrated part. SA and SA conjugates were extracted by homogenizing $1 \mathrm{~g}$ fresh weight of leaf material in liquid nitrogen containing $0.5 \mathrm{~g}$ of sea sand, followed by extractions with 70 and $90 \% \mathrm{vol} / \mathrm{vol}$ of methanol. Further steps, including highperformance liquid chromatography analysis of phenolic compounds, were carried out as described (Meuwly and Métraux 1993; Meuwly et al. 1995). Acid-soluble (PR) proteins were extracted, separated by sodium dodecyl sulfate-polyacrylamide gel electrophoresis and blotted onto nitrocellulose as described (Schweizer et al. 1997b).

The interaction of barley cv. Golden Promise with the isolate of Egh used was highly compatible, resulting in abundantly sporulating fungal colonies 5 to 6 days postinoculation. The interaction with the strain of Egt used was characterized by nonhost resistance without any macroscopic symptoms, even after prolonged incubation. The plants reacted to the isolate of Pss used here with rapid (12 to $24 \mathrm{~h}$ postinoculation) tissue necrosis of the infiltrated leaf area without any disease symptoms appearing beyond the infiltrated area within 7 days postinoculation, characteristic of a hypersensitive-type incompatible interaction.

Changes in the levels of SA and SA conjugates were determined in barley leaves at different time points after inoculation with Egh, Egt, or Pss (Fig. 1). Only injection of Pss into leaves caused a massive accumulation of SA and SA conjugates. SA was unlikely to be produced by Pss, since A. thaliana mutants deficient in SA production accumulated camalexin but not SA upon Pss infection (C. Navrath, per- 
sonal communication). Also, cultures of Pss did not produce SA (Summermatter et al. 1995). Although there was a weak, though statistically not significant (Wilcoxon's $W$ test), tendency for enhanced SA conjugates in Egt-inoculated leaves, this effect was not accompanied by enhanced levels of free SA. Inoculation of barley with Egh, Egt, or Pss caused the concerted accumulation of a set of PR proteins (Fig. 2). Rapid induction of defense-related genes in barley and other cereals even during compatible interactions is a common observation and may reflect direct responses to the formation of primary and appressorial germ tubes (see, e.g., Clark et al. 1995; Kmecl et al. 1995). The somewhat weaker induction of PR proteins by Pss might reflect accumulation only in the intact tissue neighboring the necrotic, central part, which constitutes 50 to $66 \%$ of the leaf (see above). No discrimination between necrotic and neighboring tissue of Pss-infiltrated leaves was made here. SA sprayed onto the leaves only very marginally induced the accumulation of PR proteins although, at the highest concentration applied $(10 \mathrm{mM})$, it was phytotoxic and caused necrotic leaf tips (data not shown). Other modes of SA application (soil drench and leaf injection) were not more efficient with respect to PR-protein induction (P. Schweizer, unpublished). In wheat, SA was also found to be a poor inducer of another set of genes associated with chemically induced

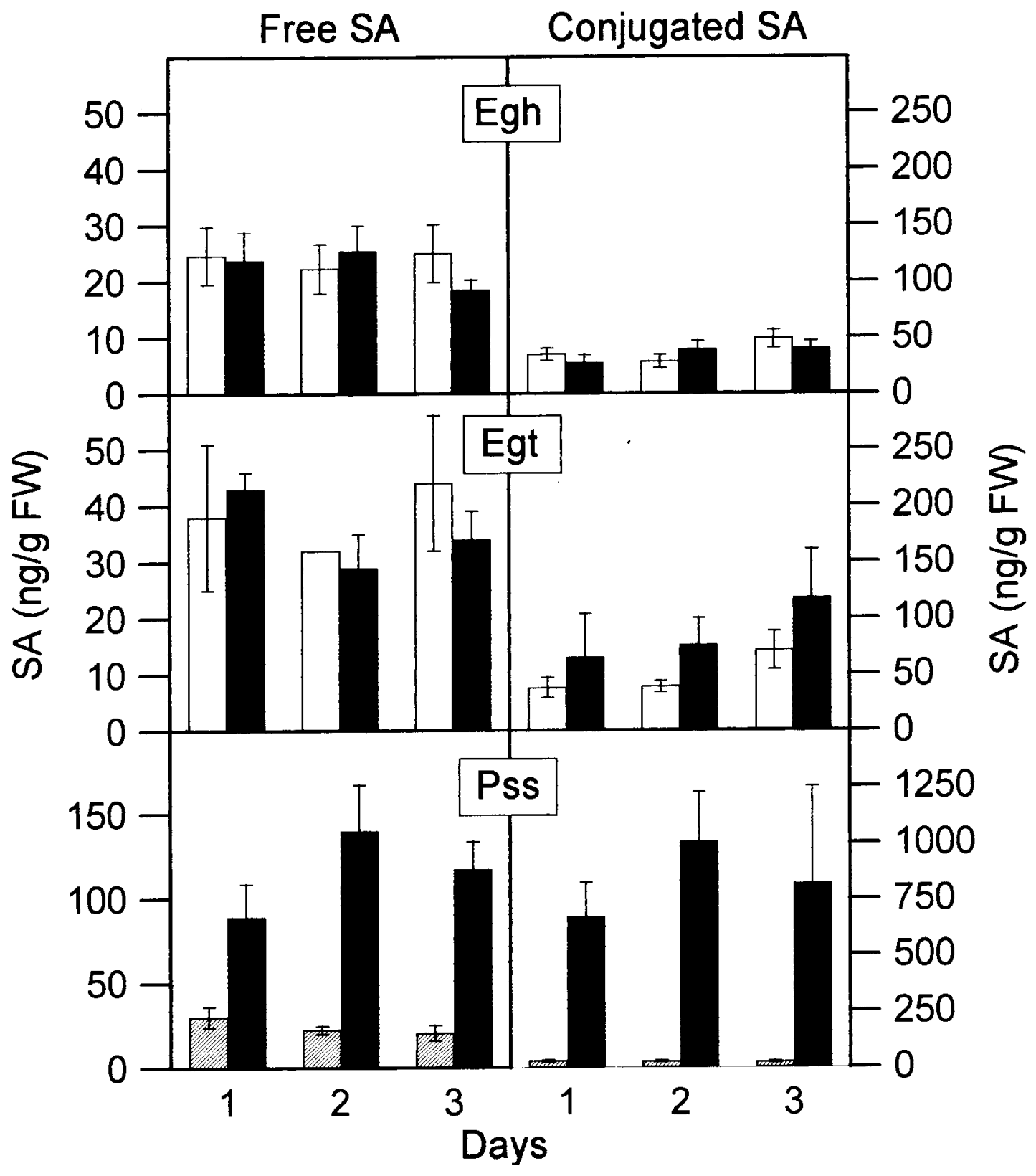

Fig. 1. Levels of salicylic acid (SA) and SA conjugates in pathogen-attacked barley leaves. First leaves of 6-day-old seedlings were inoculated with Ersiphe graminis f. sp. hordei (Egh) or Ersiphe graminis f. sp. tritici (Egt), or infiltrated with Pseudomonas syringae pv. syringae (Pss) $\left(10^{9} \mathrm{CFU}_{\mathrm{ml}}{ }^{-1}\right.$ $\mathrm{H}_{2} \mathrm{O}$ ). Controls for Egh and Egt infection remained nontreated, whereas controls for Pss infection were infiltrated with water. Leaf samples were taken 1, 2 , or 3 days postinoculation for SA determination. Open boxes $=$ nontreated control; black boxes $=$ inoculated; shaded boxes $=$ water injected. Mean values \pm SDM from 11 (Egh), 4 (Egt), or 9 (Pss) independent experiments with approximately 10 plants per sample. 
resistance whereas benzothiadiazole, a novel resistanceinducing compound, was an efficient inducer of these genes (Görlach et al. 1996).

We have demonstrated that attack of barley by three different pathogens induced the accumulation of defense-gene products such as PR1, PR3, PR5, and PR9. We have shown previously that infection of barley cv. Golden Promise with Egh also induces papilla formation (Schweizer et al. 1995, 1996). On the other hand, SA accumulation was conditional and occurred only upon inoculation with the necrotrophic Pss, but not with the biotrophic Egh or Egt. The weak enhancement of SA levels in Egt-inoculated leaves was not accompanied by enhanced levels of free SA. Since free SA is assumed to be the active form (Dempsey and Klessig 1994), the slightly enhanced levels of SA conjugates probably did not serve as a signal in barley. It cannot be excluded, however, that some enhanced SA production occurred in Egt-inoculated leaves, which was efficiently conjugated. In conclusion, SA accumulation is not required for defense-gene induction in barley. However, in the absence of barley plants expressing the bacterial salicylate hydroxylase (NahG) gene (Gaffney et al. 1993), it cannot yet be excluded that SA plays some role in barley-E. graminis interactions that is not reflected by accumulation of the compound, similar to a proposed role of jasmonic acid in pathogen-attacked rice (Schweizer et al. 1997a, 1997b). The observed SA accumulation in Pss-infected barley might be a secondary effect or stress symptom, rather than providing a signal for defense-gene induction, as proposed for other plants (Ryals et al. 1996; Schneider et al. 1996). However, a causal role of SA in the hypersensitive-type reaction to Pss cannot be excluded (Shirasu et al. 1997). The situation in barley is different from results obtained in rice, where levels of free SA were constitutively very high without increasing further upon infection by Magnaporthe grisea (Hebert) Barr. or Pss infiltration (Silverman et al. 1995).

Egt is a biological inducer of resistance in barley (Cho and Smedegaard-Petersen 1986; Ouchi et al. 1974; Schweizer et al. 1996). In conclusion, resistance induction in barley by Egt appears to be independent from SA accumulation in its active, i.e., free form. In a complementary approach, Kogel et al. (1995) showed that SA was unable to induce resistance in barley. Other possible endogenous signal molecules in pathogen-attacked plants are jasmonic acid, abscisic acid, ethylene, or $\mathrm{H}_{2} \mathrm{O}_{2}$. Based on previous findings, jasmonic acid is unlikely to play an important role as signaling compound in Egh-infected barley (Hause et al. 1997; Kogel et al. 1995; Schweizer et al. 1993). While the possible roles of ethylene or abscisic acid remain open, we have provided evidence for a signaling and resistance-mediating function of $\mathrm{H}_{2} \mathrm{O}_{2}$ in barley (Vallélian-Bindschedler et al., in press). There is increasing evidence for the existence of several pathogen-induced signaling pathways in plants, besides the SA pathway, with the combination of plant and pathogen deciding which pathway will be activated (Penninckx et al. 1996; Pieterse et al. 1996; Vidal et al. 1997). In wheat, SA and benzothiadiazole, a novel resistance-inducing compound, were very weak and strong inducers, respectively, of a set of genes that were not induced during the interaction with Egt or Egh until leaves were completely overgrown by Egt and probably severely damaged (12 days postinoculation). This suggests that, if SA is involved at all in some signaling in wheat, the pathway differs from the one activated by powdery mildew attack (Görlach et al. 1996; Schaffrath et al. 1997), in agreement with the results presented here.

\section{ACKNOWLEDGMENTS}

We thank E. Mösinger, R. Dudler, S. Muthukrishnan, and C. Somerville for their generous gifts of anti-PR1, -PR3, -PR5 and -PR9 antibodies, respectively. Assistance of G. Rhigoli with the SA analyses is acknowledged. We also thank reviewer 2 for many useful comments on the manuscript. This work was supported by Sandoz Agro Co. and in part by a grant from the Swiss National Science Foundation (grant 34098.92).
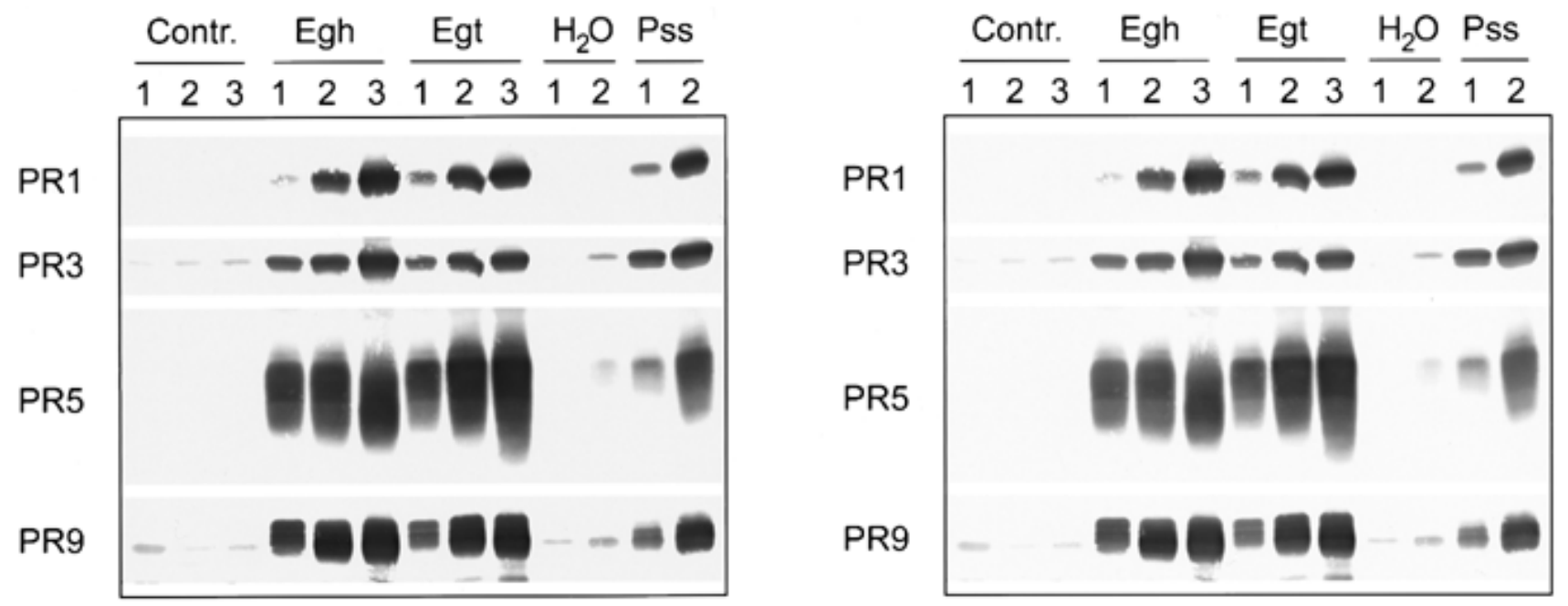

Fig. 2. Accumulation of pathogenesis-related (PR) proteins in pathogen-attacked leaves. First leaves of 6-day-old seedlings were inocul ated with Ersiphe graminis f. sp. hordei (Egh), Ersiphe graminis f. sp. tritici (Egt), or Pseudomonas syringae pv. syringae (Pss), and PR proteins were extracted 1 to 3 days postinoculation, as indicated above the respective lanes. Controls for Egh and Egt remained nontreated; controls for Pss were injected with water. PR proteins were separated by sodium dodecyl sulfate-polyacrylamide gel electrophoresis $\left(10 \mu \mathrm{g}\right.$ lane $\left.{ }^{-} 1\right)$, blotted onto nitrocellulose, and detected by antisera against PR1 of tomato (Fischer et al. 1989), PR3 of barley (Swegle et al. 1992), recombinant PR5 of wheat (Rebmann et al. 1991), and PR9 of barley (Kerby and Somerville 1992). Numbers above the lanes indicate days postinoculation. 


\section{LITERATURE CITED}

Cho, B. H., and Smedegaard-Petersen, V. 1986. Induction of resistance to Erysiphe graminis f. sp. hordei in near-isogenic barley lines. Phytopathology 76:301-305.

Clark, T. A., Zeyen, R. J., Carver, T. L. W., Smith, A. G., and Bushnell, W. R. 1995. Epidermal cell cytoplasmic events and response gene transcript accumulation during Erysiphe graminis attack in isogenic barley lines differing at the $M l$-o locus. Physiol. Mol. Plant Pathol. 46: 1-16.

Collinge, D. B., Bringelsson, T., Gregersen, P. L., Thordal-Christensen, H., and Tronsmo, A. M. 1993. The molecular and biological basis of plant disease resistance. Växtskyddsnotiser. 57:1-6.

Delaney, T. P., Uknes, S., Vernooij, B., Friedrich, L., Weymann, K., Negretto, D., Gaffney, T., Gut-Rella, M., Kessmann, H., Ward, E., and Ryals, J. 1994. A central role of salicylic acid in plant disease resistance. Science 266:1247-1249.

Dempsey, D’M. A., and Klessig, D. F. 1994. Salicylic acid, active oxygen species and systemic acquired resistance in plants. Trends Cell Biol. 4:334-338.

Fischer, W., Christ, U., Baumgartner, M., Grismann, K. H., and Mösinger, E. 1989. Pathogenesis-related proteins of tomato. II. Biochemical and immunological characterization. Physiol. Mol. Plant Pathol. 35:67-83.

Gaffney, T., Friedrich, L., Vernooij, B., Negrotto, D., Nye, G., Uknes, S., Ward, E., Kessmann, H., and Ryals, J. 1993. Requirement of salicylic acid for the induction of systemic acquired resistance. Science 261: 754-756.

Görlach, J., Volrath, S., Knauf-Beiter, G., Hengy, G., Beckhove, U., Kogel, K.-H., Oostendorp, M., Staub, T., Ward, E., Kessmann, H., and Ryals, J. 1996. Benzothiadiazole, a novel class of inducers of systemic acquired resistance, activates gene expression and disease resistance in wheat. Plant Cell 8:629-643.

Hause, B., Kogel, K.-H., Parthier, B., and Wasternack, C. 1997. In barley leaf cells, jasmonates do not act as a signal during compatible or incompatible interactions with the powdery mildew fungus (Erysiphe graminis f. sp. hordei). J. Plant Physiol. 150:127-132.

Kerby, K., and Somerville, S. C. 1992. Purification of an infectionrelated, extracellular peroxidase from barley. Plant Physiol. 100:397402.

Kmecl, A., Mauch, F., Winzeler, M., Winzeler, H., and Dudler, R. 1995. Quantitative field resistance of wheat to powdery mildew and defense reactions at the seedling stage: Identification of a potential marker. Physiol. Mol. Plant Pathol. 47:185-199.

Kogel, K.-H., Ortel, B., Jarosch, B., Atzorn, R., Schiffer, R., and Wasternack, C. 1995. Resistance in barley against the powdery mildew fungus (Erysiphe graminis f.sp. hordei) is not associated with enhanced levels of endogenous jasmonates. Eur. J. Plant Pathol. 101: $1-14$.

Malamy, J., Carr, J. P., Klessig, D. F., and Raskin, I. 1990. Salicylic acid: A likely endogenous signal in the resistance response of tobacco to viral infection. Science 250:1002-1004.

Métraux, J.-P., Singer, H., Ryals, J., Ward, E., Wyss-Benz, M., Gaudin, J., Raschdorf, K., Schmid, E., Blum, W., and Inverardi, B. 1990. Increase in salicylic acid at the onset of systemic acquired resistance in cucumber. Science 250:1004-1006.

Meuwly, P., and Métraux, J.-P. 1993. Ortho-anisic acid as internal standard for the simultaneous quantitation of salicylic acid and its putative biosynthetic precursors in cucumber leaves. Anal. Biochem. 214: 500-505.

Meuwly, P., Mölders, W., Buchala, A., and Métraux, J.-P. 1995. Local and systemic biosynthesis of salicylic acid in infected cucumber plants. Plant Physiol. 109:1107-1114.

Ouchi, S., Oku, H., Hibino, C., and Akiyama, I. 1974. Induction of accessibility and resistance in leaves of barley by some races of Erysiphe graminis. Phytopathol. Z. 79:24-34.

Penninckx, I. A. M. A., Eggermont, K., Terras, F. R. G., Thomma, B. P. H. J., De Samblanx, G. W., Buchala, A., Metraux, J.-P., Manners, J. M., and Broekaert, W. F. 1996. Pathogen-induced systemic activation of a plant defensin gene in Arabidopsis follows a salicylic acidindependent pathway. Plant Cell 8:2309-2323.
Pieterse, C. M. J., van Wees, S. C. M., Hoffland, E., van Pelt, J. A., and van Loon, L. C. 1996. Systemic resistance in Arabidopsis induced by biocontrol bacteria is independent of salicylic acid accumulation and pathogenesis-related gene expression. Plant Cell 8:1225-1237.

Rebmann, G., Mauch, F., and Dudler, R. 1991. Sequence of a wheat cDNA encoding a pathogen-induced thaumatin-like protein. Plant Mol. Biol. 17:283-285.

Ryals, J., Neuenschwander, U., Willits, M. G., Molina, A., Steiner, H.-Y., and Hunt, M. D. 1996. Systemic acquired resistance. Plant Cell 8: 1809-1819.

Schaffrath, U., Freydl, E., and Dudler, R. 1997. Evidence for different signaling pathways activated by inducers of acquired resistance in wheat. Mol. Plant-Microbe Interact. 10:779-783.

Schneider, M., Schweizer, P., Meuwly, P., and Métraux, J.-P. 1996. Systemic acquired resistance in plants. Int. Rev. Cytol. 168:303-340.

Schweizer, P., Buchala, A., and Métraux, J.-P. 1997a. Gene-expression patterns and levels of jasmonic acid in rice treated with the resistance inducer 2,6-dichloroisonicotinic acid. Plant Physiol. 115:61-70.

Schweizer, P., Buchala, A., Silverman, P., Seskar, M., Raskin, I., and Metraux, J.-P. 1997b. Jasmonate-inducible genes are activated in rice by pathogen attack without a concomitant increase in endogenous jasmonic acid levels. Plant Physiol 114:79-88.

Schweizer, P., Gees, R., and Mösinger, E. 1993. Effect of jasmonic acid on the interaction of barley (Hordeum vulgare L.) with the powdery mildew Erysiphe graminis f. sp. hordei. Plant Physiol. 102:503-511.

Schweizer, P., Jeanguenat, A., Whitacre, D., Métraux, J.-P., and Mösinger, E. 1996. Induction of resistance in barley against Erysiphe graminis f. sp. hordei by free cutin monomers. Physiol. Mol. Plant Pathol. 49:103-120.

Schweizer, P., Vallélian-Bindschedler, L., and Mösinger, E. 1995. Heatinduced resistance in barley to the powdery mildew fungus Erysiphe graminis f. sp. hordei. Physiol. Mol. Plant Pathol. 47:51-66.

Shirasu, K., Nakajima, H., Rajasekhar, V. K., Dixon, R. A., and Lamb, C. 1997. Salicylic acid potentiates an agonist-dependent gain control that amplifies pathogen signals in the activation of defense mechanisms. Plant Cell 9:261-270.

Silverman, P., Seskar, M., Dwight, K., Schweizer, P., Métraux, J.-P., and Raskin, I. 1995. Salicylic acid in rice. Plant Physiol. 108:633-639.

Smith, J. A., Hammerschmidt, R., and Fulbright, D. W. 1991. Rapid induction of systemic resistance in cucumber by Pseudomonas syringae pv. syringae. Physiol. Mol. Plant Pathol. 38:223-235.

Smith, J. A., and Métraux, J. P. 1991. Pseudomonas syringae pv. syringae induces systemic resistance to Pyricularia oryzae in rice. Physiol. Mol. Plant Pathol. 39:451-461.

Summermatter, K., Sticher, L., and Métraux, J.-P. 1995. Systemic responses in Arabidopsis thaliana infected and challenged with Pseudomonas syringae pv syringae. Plant Physiol. 108:1379-1385.

Swegle. M., Kramer, K. J., and Muthukrishnan, S. 1992. Properties of barley seed chitinases and release of embryo-associated isoforms during early stages of imbibition. Plant Physiol. 99:1009-1014.

Thordal-Christensen, H., Zhang, Z., Wei, Y. D., and Collinge, D. B. 1997. Subcellular localization of $\mathrm{H}_{2} \mathrm{O}_{2}$ in plants. $\mathrm{H}_{2} \mathrm{O}_{2}$ accumulation in papillae and hypersensitive response during the barley-powdery mildew interaction. Plant J. 11:1187-1194.

Uknes, S., Winter, A. M., Delaney, T., Vernooij, B., Morse, A., Friedrich, L., Nye, G., Potter, S., Ward, E., and Ryals, J. 1993. Biological induction of systemic acquired resistance in Arabidopsis. Mol. PlantMicrobe Interact. 6:692-698.

Vallélian-Bindschedler, L., Schweizer, P., Mösinger, E., and Métraux, J.P. Heat-induced resistance in barley to powdery mildew (Blumeria graminis f. sp. hordei) is associated with a burst of active oxygen species. Physiol. Mol. Plant Pathol. (In press.)

Vernooij, B., Friedrich, L., Morse, A., Reist, R., Kolditz Jawhar, R., Ward, E., Uknes, S., Kessmann, H., and Ryals, J. 1994. Salicylic acid is not the translocated signal responsible for inducing systemic acquired resistance but is required in signal transduction. Plant Cell 6: 959-965.

Vidal, S., Ponce de Leon, I., Denecke, J., and Palva, E. T. 1997. Salicylic acid and the plant pathogen Erwinia carotovora induce defense genes via antagonistic pathways. Plant J. 11:115-123. 